\title{
Control of the Activity through Budgeting - the Case of the Construction Companies
}

\author{
Violeta Maria Isai ${ }^{\star}$, Flavian Cireasa $^{\star \star}$
}

\begin{tabular}{l}
\hline \multicolumn{1}{c}{ A R T I C L E I N F O } \\
\hline Article history: \\
Accepted November 2020 \\
Available online December 2020 \\
\hline JEL Classification \\
L16, L60 \\
Keywords: \\
Forecast, Control, Financial \\
balance, Standardized costs
\end{tabular}

The budget of incomes and expenses, in its quality of instrument of the management of the economicfinancial activity, ensures the accomplishment of the following desideratums: integration of the forecasting activities, evidence and control regarding the expenses, the incomes and the result of the exercise; decentralization of the management process by dividing the company's activity on internal centers of income and expenses; investing each center with authority and responsibility in the management of allocated resources. For this purpose, the budget of revenues and expenditures fulfills the following functions: the function of forecasting financial activities; budget execution control function; the function of ensuring the financial balance of the company. The budget represents a financial activity plan, prepared before the period to which it refers, usually for a calendar year, with breakdown by quarters and months. A main component of the revenue and expenditure budget, which provides information to all other budgets, is the sales budget, because depending on the level of sales the company measures its production capacity, supplies and labor.

\section{Particularities of price calculation in constructions}

The construction activity presents a series of particularities that determine the way of calculating the prices, namely: the large volume of the construction works and the variety of the investment objectives; organizing the activity on site; the uniqueness of the works; the location of the objective that implies long distances and land preparation works; outdoor work.

The following price categories are used: prices per item of estimate (per operation), which are established based on the norms of estimate on consumption of materials, labor, machinery, transport and prices and tariffs on the market for materials, labor, rents, machinery; estimate prices by categories of works (groups of construction works with common characteristics: industrial, energy, housing, electrical, thermal, etc.), which are established on the basis of pre-measurements and include the entire volume of expenses occasioned by obtaining, designing, realizing, until putting into use and reaching the designed parameters; a general estimate is elaborated which represents the economic documentation through which the estimated total value of the investment objectives is established.

The price of the materials is selected by the suppliers that have the largest market share for the respective materials. For each predominant material, specific to the types of works related to the categories of works of the respective construction objective, average prices are established depending on the number of suppliers and their share on the market.

In order to contract works, the construction companies participate in the auctions, and for the substantiation of the offer price the pre-calculation is used, elaborated according to the specifications book. 
Each builder proposes the offer price at a level that will ensure the recovery of costs and profit. In addition to the price, the offer also includes the execution duration and the technical-organizational capacity of the bidder. The value of the offer is conditioned by the level of direct expenses, calculated based on the consumption of raw materials and materials, the occasioned supply expenses and the value of labor; the level of indirect expenses; the increase of the expected profit.

The technical execution details are elaborated after the conclusion of the auction based on the designers, based on the information provided by the technical project, the specifications book and premeasurements, but they also take into account the technical solutions offered by the manufacturer. Based on this information, the works estimate is drawn up, which contains the description of the works to be executed at the physical stage, the expenses necessary for the execution and their partial and total values.

The production process in constructions consists of operations, execution phases and transitions (repetition of the same technology at different intervals), defined by: execution mode (according to the estimate article), workload (quantity and units of measurement) and duration of execution (in relation to the optimal work formations).

The normative method is used to calculate construction costs. This consists in the calculation in advance of production costs based on the rules in force for each type of expenditure, as well as in the organization of an appropriate system of daily or short-term monitoring of deviations from the rules. The application of the normative method requires the performance of specific works in several stages, namely: the determination of the normed costs; organizing the record of deviations from the standardized costs; organizing the record of changes in rules; organizing the accounting of the expenses occasioned by the production process and the calculation of the costs.

The purpose of determining the standardized costs is to know in advance the cost that serves as a standard for assessing the level of cost effectiveness of the products. The standard cost is established on calculation items, according to some methodologies specific to the direct and indirect expenses. The direct standardized costs are established on the basis of a technical-economic documentation taking into account the optimal conditions of the production process, the quantitative norms in force for each cost category and the price or tariff of each direct consumption. It is determined on cost carriers using the procedure of weighting the physical quantities with the prices or unit tariffs. Indirect normed costs, expenses for maintenance and operation of equipment, common expenses of departments, and general administration expenses are determined first as absolute amounts by technical and economic calculations, and then by various calculation procedures, are distributed on cost carriers. Normative calculations, both for direct costs and for indirect costs, are the basis for determining the standardized cost of products, works or services performed.

The evidence of the deviations from the normed costs is organized both in the form of the operative record and in the accounting form, and it aims at the operative knowledge, at the same time with the development of the production process, of the deviations from the normed costs. These deviations can be materialized in savings or overruns, which are followed on each type of expense and on each work separately. Deviations from the normed costs refer both to materials and labor, as well as to the indirect and administrative expenses.

\section{Budgeting methodology}

The present research was carried out on the model of a construction company that contracted the following works for the current year: rehabilitation of a school building; pipeline repairs at a public utility company; sale of concrete to customers; provision of transport services.

In order to carry out these works, the company draws up at the beginning of the year the Budget of the revenues foreseen on the works, according to the execution and collection terms from the contracts, according to the following table:

\begin{tabular}{|l|r|r|r|r|r|}
\hline \multicolumn{1}{|c|}{ Work } & \multicolumn{1}{c|}{ Total Year } & \multicolumn{1}{c|}{ Trim I } & \multicolumn{1}{c|}{ Trim II } & \multicolumn{1}{c|}{ Trim III } & \multicolumn{1}{c|}{ Trim IV } \\
\hline $\begin{array}{l}\text { School } \\
\text { Rehabilitation }\end{array}$ & 38.000 & 7.200 & 12.600 & 12.400 & 5.800 \\
\hline $\begin{array}{l}\text { Reparation } \\
\text { and isolation }\end{array}$ & 5.700 & 800 & 2.100 & 1.600 & 1.200 \\
\hline $\begin{array}{l}\text { Sale of } \\
\text { Concrete }\end{array}$ & 85.500 & 20.000 & 24.500 & 20.000 & 21.000 \\
\hline $\begin{array}{l}\text { Transport } \\
\text { Services }\end{array}$ & 12.000 & 2.000 & 3.500 & 5.000 & 1.500 \\
\hline TOTAL & $\mathbf{1 4 1 . 2 0 0}$ & $\mathbf{3 0 . 0 0 0}$ & $\mathbf{4 2 . 7 0 0}$ & $\mathbf{3 9 . 0 0 0}$ & $\mathbf{2 9 . 5 0 0}$ \\
\hline
\end{tabular}


The cost budget is elaborated on the following sections: the budget of expenses with raw materials and direct materials; the direct labor budget; the budget of indirect and administrative expenses; the general budget of the operating expenses.

For the material expenses budget, the necessary materials are established and the consumption norms are weighted with the average price on each category, obtaining the total material expenses. From the list of materials consumption on works, it can be seen that the largest share is for the following: cement, gravel of different types and sand.

The expenses with direct labor on the work are determined by weighting the normed time on each operation with the salary tariffs per unit of time. By summing them, it results the total expenses with direct labor on the work, to which the insurance contribution for work is added.

By summing the total material expenses with the total expenses with salaries and contributions, the budget of direct expenses with materials and labor on works is obtained:

\begin{tabular}{|l|r|r|r|r|}
\hline \multicolumn{1}{|c|}{ Budget Expenses } & \multicolumn{1}{c|}{$\begin{array}{c}\text { School } \\
\text { Rehabilitation }\end{array}$} & \multicolumn{1}{c|}{$\begin{array}{c}\text { Reparation si } \\
\text { isolation }\end{array}$} & \multicolumn{1}{c|}{$\begin{array}{c}\text { Sale of } \\
\text { Concrete }\end{array}$} & \multicolumn{1}{c|}{$\begin{array}{c}\text { Transport } \\
\text { Services }\end{array}$} \\
\hline Material Expenses 100.456 & 21.018 & 1.940 & 75.553 & 1.945 \\
\hline $\begin{array}{l}\text { Salary expenses + quotas } \\
25.407\end{array}$ & 12.372 & 2.972 & 1.761 & 8.302 \\
\hline $\begin{array}{l}\text { Total General } \\
\text { 125.863 }\end{array}$ & 33.390 & 4.912 & 77.314 & 10.247 \\
\hline
\end{tabular}

The elaboration of the budget of indirect expenses, supposes first the elaboration of analytical budgets of indirect expenses, separated on groups and types of expenses.

For fixed expenses, the procedure is different depending on their content: the expenses with the salaries of indirectly productive staff are estimated according to the staff policy, the foreseeable changes in the staff structure and the level of salary provided for the budgeted period; depreciation is calculated taking into account the depreciation plan, the depreciation system adopted and the changes provided in the structure of fixed assets; consumables and other expenses depending on the achievements of the previous period, with the corrections imposed by the economic situation of the budgeted period.

For variable indirect expenditures, it is proceeded in a similar way as for direct costs, when there is the possibility to determine them based on calculations or based on correlation with the production volume, taking into account the achievements of previous periods and the inflation index.

The budget of general administration expenses consists in programming these expenses, analytically by groups of expenses, and within the groups by types of expenses. The expenses incurred by these activities are difficult to control and with a tendency to increase, being complex, multiple, inhomogeneous, hence the impossibility to have a unit of activity. For this reason, a global budget is established for all compartments, which cannot be exceeded, based on expenditures from the previous period, corrected according to the forecasts on price increases for materials and labor, after which each compartment determines its own forecasts (monthly energy consumption is determined by flat rate, taking into account the installed capacity of electronics currently consuming for administrative purposes, the electricity purchase rate is relatively constant; water consumption is determined based on the water meter reading, water tariff and sewerage is unique, the cost of telephony services is determined based on the monthly subscription paid, the costs of banking services include the costs of settlement fees, according to the bank account statements, the costs of taxes and fees refer to the building tax company property as well as car taxes; costs for administrative staff include the salaries and related contributions.

The indirect and administration budgeted expenses to be made in the analyzed period are presented in the following table:

\begin{tabular}{|l|r|r|r|r|}
\hline \multicolumn{1}{|c|}{ Budget Expenses } & \multicolumn{1}{|c|}{$\begin{array}{c}\text { Mechanic } \\
\text { Workshop }\end{array}$} & Transport Sector & $\begin{array}{c}\text { Concrete } \\
\text { Station }\end{array}$ & Total General \\
\hline Indirect Expenses & 1.239 & 550 & 335 & 2.124 \\
-variable & 2.499 & 4.315 & 1.338 & 8.152 \\
-fixed & & & & \\
\hline Administrative & - & - & - & 586 \\
Expenses & - & - & - & 1.003 \\
-variable & 3.738 & 4.865 & 1.673 & 11.865 \\
-fixed & & & & \\
\hline Total general & & & & \\
\hline
\end{tabular}


Indirect and administrative expenses are distributed on works, choosing as the basis for the distribution the total direct expenses. The distribution coefficient $(\mathrm{k}=11.865 / 125.863=0.094)$ is multiplied by the total direct expenses on each work, determining the share of expenses related to the respective work. By assembling the partial budgets, the general budget of revenues and expenditures forecasted on works is prepared, presented in the following table:

\begin{tabular}{|c|c|c|c|c|c|}
\hline INDICATORS & $\begin{array}{l}\text { COMPANY } \\
\text { TOTAL }\end{array}$ & $\begin{array}{c}\text { School } \\
\text { Rehabilitation }\end{array}$ & $\begin{array}{l}\text { Pipeline } \\
\text { Repairs }\end{array}$ & $\begin{array}{c}\text { Concrete } \\
\text { Sales }\end{array}$ & Transports \\
\hline $\begin{array}{l}\text { Revenues from sales of } \\
\text { finished products }\end{array}$ & 85.500 & 0 & 0 & 85.500 & 0 \\
\hline $\begin{array}{l}\text { Revenues from works and } \\
\text { services provided }\end{array}$ & 43.700 & 38.000 & 5.700 & 0 & 0 \\
\hline $\begin{array}{lll}\text { Income } & \text { from } & \text { various } \\
\text { activities } & & \\
\end{array}$ & 12.000 & 0 & 0 & 0 & 12.000 \\
\hline TOTAL INCOME & 141.200 & 38.000 & 5.700 & 85.500 & 12.000 \\
\hline Material expenses & 100.267 & 21.018 & 1.940 & 75.364 & 1.945 \\
\hline $\begin{array}{|lll|}\begin{array}{l}\text { Energy } \\
\text { expenses }\end{array} & \text { and water } & \\
\end{array}$ & 189 & 0 & 0 & 189 & 0 \\
\hline Salary expenses & 24.849 & 12.100 & 2.907 & 1.722 & 8.120 \\
\hline $\begin{array}{l}\text { Expenditures with salary } \\
\text { quotas }\end{array}$ & 559 & 272 & 65 & 38 & 182 \\
\hline $\begin{array}{|ll|}\text { TOTAL } & \text { DIRECT } \\
\text { EXPENSES } & \\
\end{array}$ & 125.863 & 33.390 & 4.912 & 77.314 & 10.247 \\
\hline $\begin{array}{ll}\text { Indirect } & \text { and } \\
\text { administrative expenses }\end{array}$ & 11.865 & 3.147 & 464 & 7.288 & 966 \\
\hline TOTAL EXPENSES & 137.728 & 36.537 & 5.376 & 84.602 & 11.213 \\
\hline $\begin{array}{l}\text { GROSS RESULT ON } \\
\text { WORKS }\end{array}$ & 3.472 & 1.463 & 324 & 898 & 787 \\
\hline PROFIT TAX & 556 & 234 & 52 & 144 & 126 \\
\hline NET RESULT & 2.916 & 1.229 & 272 & 754 & 661 \\
\hline
\end{tabular}

The general budget will be broken down into trimesters and will be a benchmark of the activity of the construction company for the analyzed period, for each type of work and for each category of income and expenses.

\section{Research results}

The company records the deviations between the forecasted level of incomes and expenses and their effective level, formulating conclusions and finding solutions to correct the unfavorable aspects.

\begin{tabular}{|l|r|r|r|}
\hline \multicolumn{1}{|c|}{ INDICATORS } & \multicolumn{1}{|c|}{ Preliminary } & \multicolumn{1}{|c|}{ ACCOMPLISHED } & +820 \\
\hline $\begin{array}{l}\text { Revenues from sales of } \\
\text { finished products }\end{array}$ & 85.500 & 86.320 & 0 \\
\hline $\begin{array}{l}\text { Revenues from works and } \\
\text { services provided }\end{array}$ & 43.700 & 43.700 & +930 \\
\hline $\begin{array}{l}\text { Revenues from various } \\
\text { activities }\end{array}$ & 12.000 & 12.930 & $\mathbf{+ 1 . 7 5 0}$ \\
\hline TOTAL INCOME & $\mathbf{1 4 1 . 2 0 0}$ & $\mathbf{1 4 2 . 9 5 0}$ & +5.101 \\
\hline Expenses with raw materials & 100.267 & 105.368 & +660 \\
\hline Other material expenses & 2.265 & 2.925 & +41 \\
\hline $\begin{array}{l}\text { Expenses with energy and } \\
\text { water }\end{array}$ & 523 & 482 & +31 \\
\hline $\begin{array}{l}\text { Expenses with services } \\
\text { provided by third parties }\end{array}$ & 609 & 640 & +676 \\
\hline Expenses with Staff & 32.969 & 33.645 & +15 \\
\hline Expenses with salary quotas & 742 & 757 & 0 \\
\hline $\begin{array}{l}\text { Expenses with depreciation } \\
\text { and provision }\end{array}$ & 353 & 353 & \\
\hline
\end{tabular}




\begin{tabular}{|l|r|r|r|}
\hline TOTAL EXPENSES & $\mathbf{1 3 7 . 7 2 8}$ & $\mathbf{1 4 4 . 1 7 0}$ & $\mathbf{+ 6 . 4 4 2}$ \\
\hline GROSS RESULT & $\mathbf{3 . 4 7 2}$ & $\mathbf{1 . 2 2 0}$ & $\mathbf{- 2 . 2 5 2}$ \\
\hline Profit Tax & 556 & 195 & -361 \\
\hline NET RESULT & & & $\mathbf{- 1 . 8 9 1}$ \\
\hline
\end{tabular}

From the analysis of the deviations from the total forecasted revenues and expenses, it results that the company exceeded the forecasted revenues from various activities (transport for third parties) and from concrete production.

At the same time, there were overruns for all categories of expenses, the most significant overruns being for the expenses with materials and staff expenses. These exceedances in material and labor costs are mainly due to the increase in prices for materials over those forecasted, exceeding the forecasted consumption and labor tariffs.

\section{Conclusions}

The elaboration of the budgets of incomes and expenses within the construction companies represents an instrument of analysis and control of the activity, considering the special conditions in which their activity is carried out. Offering the possibility of calculating deviations by types of income and expenses, the company can adopt in time the measures required to eliminate excesses to certain categories of expenses by: compliance with the criterion of economic efficiency, respectively selling prices and tariffs to cover costs and allow profit increase; avoiding the contracting of works with fixed tariffs that extend over long periods of execution, taking into account the eventual increases of the prices of materials and utilities; performing precalculations without oversizing consumption; concluding firm contracts with suppliers of raw materials and materials in order to establish a rhythmic supply and avoid syncopes; diversifying the supply of raw materials from several suppliers; permanent monitoring of compliance with normed consumption; performing the factorial analysis of the exceedances of materials and labor.

\section{References}

1. Arnold M., Artz M.-The use of a single budget or separate budgets foe planning and performance evaluation, Accounting, Organizations and Society, 2019

2. Chi Y., Ziebart D.A.-Evidence regarding management's choice of forecast precision, Journal of forensing\&Investigative Accounting, 2019

3. Dumbrava P.-Contabilitatea de gestiune in constructii, Ed. Intelcredo, Deva, 2000

4. Nikias A.D.-An experimental examination of the effects of information control on budget reporting with relative project evaluation, Journal of Management Accounting Research, 2019

5. Olando J.-Turning budgeting pain into budgeting gain, Strategic Finance, 2009

6. SchoemakerP.J.H., Tetlock P.E.-Superforcasting: How to upgrade your company's judgement, Harvard Business Review, 2016 